\title{
Peningkatan hasil belajar dan jiwa kompetitif siswa SMK menggunakan team game tournament
}

\author{
Dyah Ayu Anggraeni \\ SMK Muhammadiyah 1 Sleman. Jl. Agrowisata No.KM. 01, Panggeran 9, Triharjo, Sleman, Daerah Istimewa Yogyakarta 55514, Indonesia \\ anggraenidyahayu@gmail.com \\ * corresponding author
}

ARTICLE INFO

Keywords

Hasil belajar

Jiwa Kompetitif

Team Game Tournament

\section{ABSTRACT}

Penelitian ini bertujuan untuk mengetahui peningkatan jiwa kompetitif dan hasil belajar pada mata pelajaran kewirausahaan dengan mengimplementasikan model pembelajaran Team GeamTournament (TGT) bagi peserta didik kelas X TKR 3 SMK Muhammadiyah 1 Sleman. Jenis penelitian ini merupakan Penelitian Tindakan Kelas (PTK) dengan menggunakan model TGT. Terjadi peningkatan hasilbelajarpeserta didik setelah diimplementasikan model pembelajaran TGT,rata-rata nilai untuk siklus 1 adalah 46,sedangkan rata-rata nilai siklus 2 adalah 56,79 dan rata-rata nilai untuk siklus 3 sudah mencapai 75,59. Pada siklus 1 hanya satu peserta didik yang nilainya mencapai KKM sedangkan di siklus 2 mengalami peningkatan jumlah peserta didik yang nilainya mencapai KKM sebanyak 3 peserta didik. Pada siklus 3 sebanyak 19 peserta didik, sehingga ada 10 orang peserta didik yang belum dapat mencapai KKM. Selain pada hal hasil belajar, hasil penelitian ini juga menjelaskan bahwa adanya kenaikan jiwa kompetitif peserta didik yaitu adanya persaingan yang sehat untuk mendapatkan skor dan nilai tertinggi di kelas. Selain itu peserta didik juga memiliki motivasi untuk belajar dan bersaing dikelas.

This is an open access article under the CC-BY-SA license.

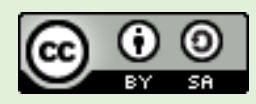

\section{PENDAHULUAN}

Pendidikan merupakan salah satu sektor penting dalam pembangunan disetiap negara. Menurut Undang-Undang Republik Indonesia Nomor 20 Tahun 2003 Tentang Sistem Pendidikan Nasional (2003) Pasal 1, Pendidikan adalah usaha sadar dan terencana untuk mewujudkan suasana belajar dan proses pembelajaran agar peserta didik secara aktif mengembangkan potensi dirinya untuk memiliki kekuatan spiritual keagamaan, pengendalian diri, kepribadian, kecerdasan, akhlak mulia, serta keterampilan yang diperlukan dirinya, masyarakat, bangsa dan negara. Salah satu usaha mewujudkan tujuan pendidikan adalah dengan adanya suatu instansi pendidikan yaitu sekolah. Salah satu sekolah ditingkat menengah atas adalah Sekolah Menengah Kejuruan (SMK), menurut Undang-Undang Republik Indonesia Nomor 20 Tahun 2003 Tentang Sistem Pendidikan Nasional (2003) Pasal 15 Pendidikan kejuruan merupakan pendidikan menengah yang mempersiapkan peserta didik terutama untuk bekerja di bidang tertentu.

Beradasarkan penjelasan tersebut maka peserta didik SMK diharapkan memiliki kemandirian, kemampuan mengembangkan diri secara professional agar dapat bekerja di bidang tertentu sesuai dengan keahliannya. Semakin berkembangnya era globalisasi kemampuan seseorang dalam mena- 
ngani sesuatu juga harus terus dikembangkan agar dapat terus mengikuti perkembangan jaman. Untuk mendukung itu semua perlu adanya mata pelajaran kewirausahaan di SMK.

Mata pelajaran kewirausahaan di SMK diharapkan dapat mewujudkan tujuan dari SMK melalui materi-materi yang ada (Lastariwati, 2012). Berhasil atau tidaknya suatu pembelajaran tergantung dari seluruh komponen yang ada, baik peserta didik dan guru sama-sama berperan, guru diharapkan dapat kreatif dan inovatif dalam mengajar, sehingga peserta didik tidak lebih termotivasi untuk belajar, serta dapat menjadikan lulusan yang memiliki jiwa kompetitif dan hasil belajar yang sesuai dengan kriteria yang ada. Perlu adanya suatu model pembelajaran yang menyenangkan dan tidak monoton supaya dapat menjadikan peserta didik lebih aktif, kreatif, mampu bersaiang sehat dan bersemangat untuk belajar, sehingga hasil belajar akan meningkat.

Berkaitan dengan aspek peningkatan hasil, penelitian ini mencoba mengamati permasalahan pada mata pelajaran kewirausahaan di SMK Muhammadiyah 1 Sleman yang masih memiliki kendala hasil belajar yang rendah, belum semua peserta didik dapat mencapai Kriteria Ketuntasan Minimal sebesar 75. Setelah mengadakan observasi awal, dapat ditemukan penyebabnya yaitu karena selama ini guru masih terbatas menggunakan model pembelajaran konvensional yaitu guru hanya menggunakan metode ceramah satu arah yang disajikan dalam teori-teori kompleks sehingga mengurangi minat peserta didik untuk mempelajari dan mempraktikannya secara lebih dalam. Kebanyakan peserta didik hanya mencatat dan menghafal apa yang diberikan oleh guru, sehingga pembelajaran menjadi monoton dan tidak menyenangkan yang menyebabkan peserta didik akan menjadi bosan dan kurang aktif dalam menyampaikan ide atau gagasannya karena hanya menerima informasi saja, peserta didik juga kurang bisa berkompetitif untuk memperoleh nilai yang tinggi.

Metode pembelajaran tidak boleh membatasi ruang kreatifitas peserta didik untuk mengkontruksi ide-ide mereka. Berbagai teori, penelitian dan pelaksanaan pembelajaran membuktikan bahwa guru sudah harus mengubah metode pembelajaran ceramah yang diterapkan secara murni tersebut dengan menyusun dan melaksanakan pembelajaran yang lebih mengasyikan. Salah satu model pembelajaran yang bisa digunakan adalah model kooperatif. Menurut Lie (2008) pembelajaran kooperatif adalah sistem pengajaran yang memberi kesempatan kepada anak didik untuk bekerjasama dengan sesama peserta didik dalam tugass- tugas yang memasukkan unsur-unsur keterlibatan peserta didik secara langsung. Pembelajaran kooperatif merupakan salah satu pembelajaran yang dikembangkan dari teori konstruktivisme karena mengembangkan sstruktur kognitif untuk membangun pengetahuan sendiri melalui berfikir

Alternatif model pembelajaran yang dapat diterapkan yaitu pembelajaran kooperatif tipe TGT (Teams Games Tournament) (Fahruddin et al., 2017; Nurwidia et al., 2019; van Wyk, 2011). Model pembelajaran ini banyak melibatkan peserta didik secara langsung dalam mengerjakan soal-soal serta keterlibatan teman sebaya yang berkemampuan akademik tinggi dalam kelompok-kelompok belajar di kelas dapat memudahkan peserta didik dalam memahami materi pelajaran, peserta didik bisa aktif di kelas untuk menyampaikan ide dan gagasannya, motivasi peserta didik pun akan tinggi karena ada tahap kompetitif yang memacu peserta didik mendapatkan nilai tinggi dengan kompetitif yang sehat tersebut, sehingga peserta didik dapat dengan mudah memahami materi yang ada dan hasil belajarpun akan meningkat.

TGT terdiri dari serangkaian kegiatan meliputi Teaching (Presentasi dan pengajaran oleh guru), Team Study atau belajar secara tim (kelompok), Tournament (perlombaan) dan recognition (pengakuan dan penganugerahan). Pembelajaran dilakukan yaitu dimana peserta didik setelah belajar kelompok diadakan turnamen akademik, peserta didik akan berkompetitif sebagai wakil dari kelompoknya dengan anggota dari kelompok lain. TGT lebih ditekankan kepada Gaming (permainan) yaitu kegiatan belajar yang menghendaki peserta didik berkompetitif atau berlomba baik fisik maupun mental sesuai dengan aturan permainan yang ditetapkan. Dalam model ini harus ada yang menang dan yang kalah.

Model pembelajaran kooperatif unggul dalam membantu peserta didik memahami konsepkonsep sulit dan memberikan efek terhadap sikap penerimaan perbedaan antar-individu, baik ras, keragaman budaya, gender, sosial-ekonomi, dll. Selain itu yang terpenting pembelajaran kooperatif 
mengajarkan keterampilan bekerja sama dalam kelompok atau teamwork. Keterampilan ini sangat dibutuhkan peserta didik saat nanti lepas ke tengah masyarakat, terlebih lulusan otomotif yang dituntut untuk terjun ke dunia usaha. Dengan menggunakan model pembelajaran TGT diharapkan hasil belajar peserta didik pada mata pelajaran kewirausahaan akan meningkat, karena pembelajaran kewirausahaan adalah salah satu mata pelajaran yang berisi teori yang dapat dikembangkan dan disampaikan dalam bentuk diskusi dan kompetitif sehingga cocok untuk diterapkan pada model pembelajaran TGT. Dengan demikian, dari penelitian ini diharapkan permasalahan yang terjadi di sekolah dapat diatasi dengan diterapkannya model pembelajarn TGT dengan beberapa keunggulannya.

\section{HASIL DAN PEMBAHASAN}

\section{Pelaksanaan pada siklus I}

Proses belajar mengajar pembelajaran kewirausahaan pada siklus I adalah sebagai berikut: (1) Dalam proses belajar mengajar terdapat $100 \%$ atau 29 peserta didik yang mengikuti pelajaran, (2) Hanya ada satu peserta didik yang telah mencapai KKM, (3) Hasil belajar peserta didik dari TGT yang telah dilakukan pada siklus I, nilai dijelaskan dalam tabel berikut sesuai perolehan masingmasing team:

Tabel 1. Hasil perolehan skor kelompok pada siklus I

\begin{tabular}{cccc}
\hline Nama Kelompok & Skor game kartu & Poin turnamen & Predikat Tim \\
\hline A & 30 & 50 & \\
B & 30 & 50 & JUARA 1 \\
C & 50 & 50 & JUARA 3 \\
D & 50 & 20 & \\
E & 60 & 30 & JUARA 2 \\
F & 40 & 40 & 50 \\
\hline
\end{tabular}

Berdasarkan Tabel 1 dapat dijelaskan bahwa tim yang memiliki predikat juara 1 adalah kelompok C perolehan total skor sebesar 100 yang didapat dari skor game kartu dan skor turnamen. Setelah melaksanakan tindakan refleksi pada siklus I terdapat beberapa kelemahan yang harus diperbaiki pada siklus II, diantaranya yaitu: (a) Waktu kurang di kelola dengan baik sehingga sedikit melebihi batas waktu yang ditentukan. Pada siklus selanjutnya guru harus lebih memperhatikan waktu yang telah dibuat di RPP, sehingga waktu bisa optimal dan tidak melebihi waktu yang disediakan, (b) Peserta didik masih bingung ketika pertama kali dijelaskan tentang permainan, dijelaskan dengan pelan dan beberapa kali bertanya peserta didik baru benar-benar paham. Sebaiknya membuat game yang lebih mudah dimengerti oleh peserta didik, tetapi untuk siklus II peserta didik sudah paham dengan tournament karena sama dengan game siklus I sehingga untuk tournament masih sama dengan siklus I, (c) Peserta didik masih belum optimal dalam diskusi, masih ada yang ngobrol dan kurang serius. Guru lebih mengawasi peserta didik supaya tidak mengobrol sendiri dan lebih serius.

\section{Pelaksanaan pada siklus II}

Tabel 2. Hasil perolehan skor kelompok pada siklus 2

\begin{tabular}{cccc}
\hline Nama Kelompok & Skor game kartu & Poin turnamen & Predikat Tim \\
\hline A & 40 & 45 & JUARA 3 \\
B & 40 & 50 & JUARA 2 \\
C & 50 & 50 & JUARA 1 \\
D & 30 & 30 & \\
E & 40 & 30 & \\
F & 20 & 50 & \\
G & 50 & 30 & \\
\hline
\end{tabular}


Proses belajar mengajar pembelajaran kewirausahaan pada siklus II adalah sebagai berikut: (1) Dalam proses belajar mengajar terdapat $100 \%$ atau 29 peserta didik peserta didik mengikuti pelajaran, (2) Ada tiga peserta didik yang telah mencapai KKM, (3) Hasil belajar peserta didik dari game yang telah dilakukan pada siklus 2, nilai dijelaskan dalam tabel berikut sesuai perolehan masing-masing team. Berdasarkan Tabel 2 dapat dijelaskan bahwa tim yang memiliki predikat juara 1 adalah kelompok $\mathrm{C}$ perolehan total skor sebesar 100 yang didapat dari skor game kartu dan skor turnamen

\section{Pelaksanaan pada siklus III}

Proses belajar mengajar pembelajaran kewirausahaan pada siklus III adalah sebagai berikut: (1) Dalam proses belajar mengajar terdapat $100 \%$ atau 29 peserta didik peserta didik mengikuti pelajaran, (2) 19 peserta didik telah mencapai KKM, (3) Hasil belajar peserta didik dari game yang telah dilakukan pada siklus 2, nilai dijelaskan dalam tabel berikut sesuai perolehan masing-masing team.

Tabel 3. Hasil perolehan skor kelompok pada siklus III

\begin{tabular}{cccc}
\hline Nama Kelompok & Skor game kartu & Poin turnamen & Predikat Tim \\
\hline A & 40 & 40 & JUARA 3 \\
B & 40 & 20 & \\
C & 50 & 10 & JUARA 1 \\
D & 40 & 50 & \\
E & 40 & 30 & JUARA 2 \\
F & 40 & 45 & \\
G & 50 & 30 & \\
\hline
\end{tabular}

Berdasarkan Tabel 3 dapat dijelaskan bahwa tim yang memiliki predikat juara 1 adalah kelompok D perolehan total skor sebesar 90 yang didapat dari skor game kartu dan skor turnamen

\section{Peningkatan Hasil Belajar Kewirausahaan Peserta didik Menggunakan Model pembelajaran TGT}

Hasil pengamatan berdasarkan lembar penilaian tentang variabel hasil belajar kewirausahaan dari siklus 1, 2 dan 3 diperoleh data sebagai berikut:

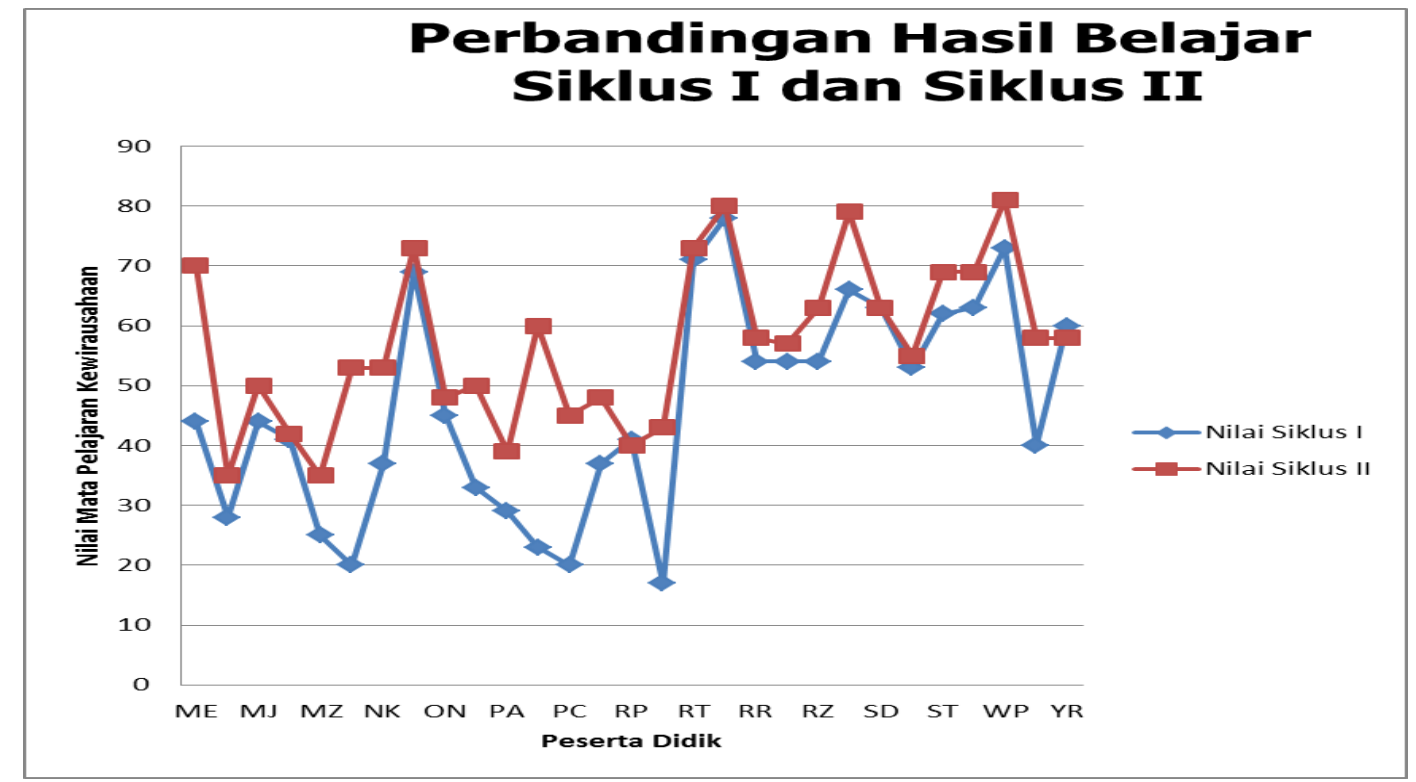

Gambar 1. Perbandingan hasil belajar siklus 1 dan 2 


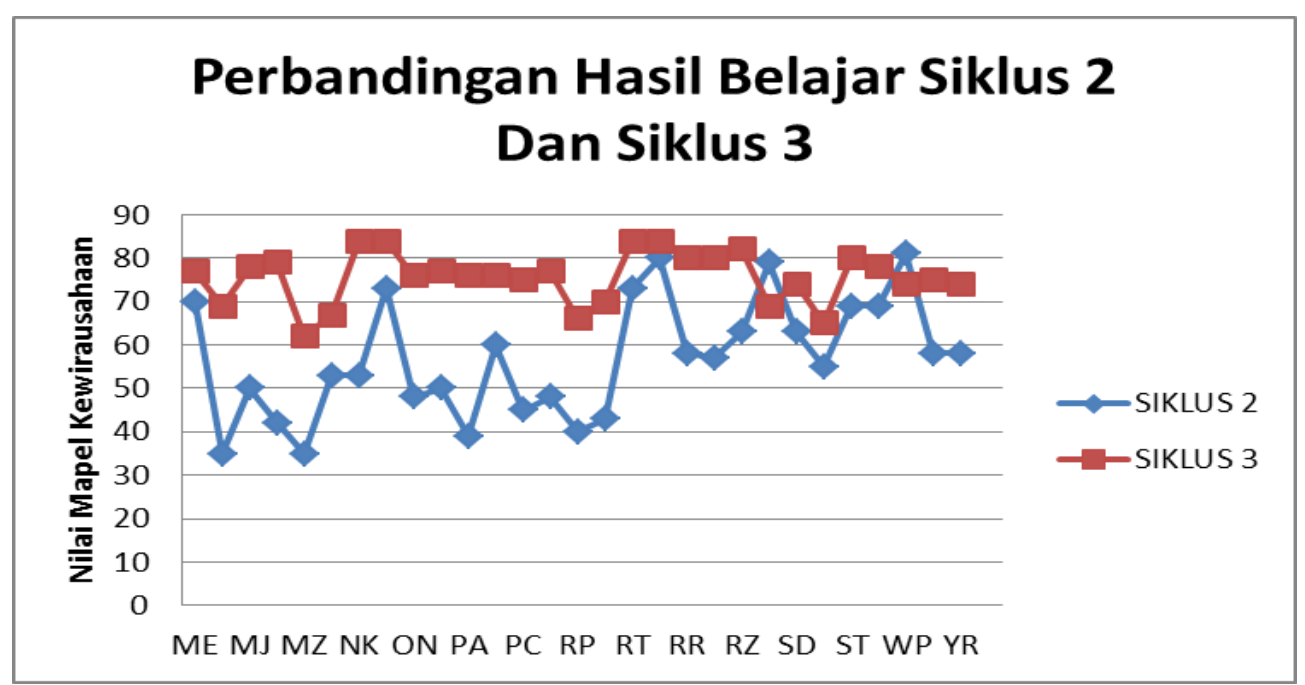

Gambar 2. Perbandingan hasil belajar siklus 2 dan 3

Berdasarkan data diatas maka diketahui peningkatan hasil belajar peserta didik selain dapat dilihat dari prestasi nilai masing-masing peserta didik, juga dapat dilihat melalui peningkatan ratarata kelas, yaitu rata-rata nilai untuk siklus I adalah 46,34 jika dibandingkan dengan pencapaian KKM masih belum memenuhi, sedangkan rata-rata nilai siklus II adalah 56,79 dan rata-rata nilai untuk siklus III sudah mencapai 75,59. Pada siklus I hanya satu peserta didik yang nilainya mencapai KKM sebesar 75, sedangkan di siklus II mengalami peningkatan jumlah peserta didik yang nilainya mencapai KKM sebanyak 3 peserta didik. Dan pada siklus III sebagian besar peserta didik telah dapat mencapai KKM yaitu sebanyak 19 peserta didik, sehingga ada 10 orang peserta didik yang belum dapat mencapai KKM.

Peningkatan hasil belajar peserta didik dapat diketahui dari hasil pengamatan yang dilakukan saat tindakan. Pengamatan dilakukan terhadap proses belajar dan hasil belajar peserta didik. Pengamatan proses belajar mengajar dilihat berdasarkan lembar observasi, kegiatan apa saja yang dilakukan peserta didik, jiwa kompetisi dan keaktifan peserta didik pada saat diskusi tahap team, aktif menjawab pertanyaan dan semangat berkompetisi yang sehat antar kelompok pada tahap game and tournament. Kegiatan tersebut dapat dijelaskan berikut ini:

\section{Peningkatan jiwa kompetitif peserta didik menggunakan model pembelajaran TGT}

Adapun Indikator yang digunakan untuk mengukur peningkatan jiwa kompetitif peserta didik adalah dengan melihat keberanian dan kepercaya dirian peserta didik dalam menyampaikan pendapatnya, dan sportif dalam perlombaan. Adapun hasil observasi terhadap jiwa kompetitif peserta didik pada setiap siklusnya dapat dilihat sebagai berikut.

Pada siklus pertama jiwa kompetitif peserta didik belum terlihat dapat dibuktikan dengan masih banyak peserta didik yang belum berani menyampaikan pendapatnya. Selain hal itu masih banyak peserta didik yang melakukan aktivitas lain daripada mengikuti pembelajaran dengan metode TGT. Dari hasil observasi hanya ada 3 anak yang berani menyampaikan pendapat di depan temantemannya.

Pada siklus kedua jiwa kompetitif peserta didik mulai Nampak dibuktikan dengan semakin banyak peserta didik yang berani mengungkapkan pendapatnya. Serta sudah banyak peserta didik yang belajar dengan tekun agar menang dalam tournament.

Pada siklus ketiga jiwa kompetitif peserta didik sudah terlihat meski belum semua akan tetapi sudah lebih banyak dari siklus sebelumnya. Hasil aktivitas peserta didik menunjukkan bahwa peserta didik mampu mengendalikan rasa ingin menang sendiri (egois). Hal ini terlihat terdapat peserta didik masih menganggap pendapatnya sendiri yang paling benar dan tidak mau mendengarkan pendapat yang berbeda dari temannya. Namun, terdapat pula peserta didik yang sudah mampu mendengarkan pendapat teman lain saat mengerjakan tugas kelompok. 
Saat pembelajaran, terdapat peserta didik yang memberi semangat kepada temannya agar mendapat nila iyang bagus. Pada saat diskusi terdapat teman yang belum paham diberi motivasi dan dijelaskan agar pada saat tournament kelompoknya dapat menjadi juara. Pada saat tournament peserta didik mengerjakan sendiri sesuai kemampuannya dan nilai dari masing-masing peserta didik dikumpulkan.

Berdasarkan hasil observasi peserta didik peserta didik senang ketika teman berhasil mencapai hal yang diinginkan ditunjukkan dengan bertepuk tangan dan memberi selamat. Dalam observasi juga terdapat peserta didik yang senang apabila kelompok yang lain mendapat nilai bagus. Hal tersebut terlihat dengan memberi selamat dan ikut bertepuk tangan saat kelompok yang mendapat juara. Berdasarkan uraian hasil observasi aktivitas peserta didik selama proses pembelajaran, maka dapat disimpulkan bahwa peserta didik menunjukkan meningkatnya jiwa kompetitif.

\section{SIMPULAN}

Berdasarkan penelitian dan pembahasan tentang implementasi model pembelajaran Team Game Tournamen (TGT) untuk meningkatkan hasil belajar Kewirausahaan peserta didik kelas X TKR 3 SMK Muh 1 Sleman, maka dapat diambil simpulan sebagai berikut: Pertama implementasi model pembelajaran TGT dapat meningkatkan hasil belajar peserta didik dilaksanakan menggunakan model penelitian tindakan Kemmis \& McTaggart dengan empat tahapan yaitu: (a) Perencanaan (plan) yaitu peneliti melakukan rancangan tindakan yang menjelaskan tentang apa, mengapa, kapan,dimana,oleh siapa dan bagaimana tindakan tersebut dilakukan,dan membuat instrumen, RPP dan perlengkapan lain untuk melaksanakan tindakan. (b) tindakan (do) yaitu penerapan dari model pembelajaran TGT yaitu dimulai dari pembagian kelompok (Team) yang terdiri dari penjelasan peraturan permainan, pembagian peran masing-masing kelompok dan menjelaskan alur peran kelompok, selanjutnya adalah keberlangsungan game and tournament tersebut, dan yang terakhir adalah recognize team yaitu pengumuman pemenang game kompetisi yang telah selesai dilaksanakan kemudian pemberian penghargaan tim terbaik. (c) Pengamatan (observing) yaitu pelaksanaan pengamatan oleh peneliti dan teman sejawat dengan menggunakan lembar observasi dan instrument lainnya. (d) refleksi (see) yaitu mengemukakan kembali apa yang sudah terjadi. Proses pembelajaran dilaksanakan oleh guru yang dilaksanakan dengan tiga siklus, masing-masing siklus dua pertemuan pada mata pelajaran kewirausahaan sesuai jadwal yang ada pada sekolah selama 2 jam pelajaran. Peserta didik cukup antusias dan senang dalam belajar sehingga memotivasi peserta didik untuk bisa lebih bersemangat dalam pelaksanaan game dan turnamen.

Kedua hasil belajar peserta didik setelah diimplementasikan model pembelajaran TGT dalam pembelajaran kewirausahaan adalah adanya peningkatan. Rata-rata nilai untuk siklus 1 adalah 46,34 jika dibandingkan dengan pencapaian KKM masih belum memenuhi, sedangkan rata-rata nilai siklus 2 adalah 56,79 dan rata-rata nilai untuk siklus 3 sudah mencapai 75,59. Pada siklus 1 hanya satu peserta didik yang nilainya mencapai KKM sebesar 75, sedangkan di siklus 2 mengalami peningkatan jumlah peserta didik yang nilainya mencapai KKM sebanyak 3 peserta didik. Dan pada siklus 3 sebagian besar peserta didik telah dapat mencapai KKM yaitu sebanyak 19 peserta didik, sehingga ada 10 orang peserta didik yang belum dapat mencapai KKM.

Ketiga selain padahal hasil belajar, hasil penelitian ini juga menjelaskan bahwa peserta didik dapat belajar dengan aktif yaitu adanya interaksi antar guru dan peserta didik, komunikasi saat diskusi dan presentasi juga dapat menjadikan peserta didik lebih aktif dan memahamkan peserta didik tentang materi yang diajarkan oleh guru. Peserta didik juga kompetitif yaitu adanya persaingan yang sehat untuk mendapatkan skor dan nilai tertinggi di kelas, Selain itu peserta didik juga memiliki motivasi untuk belajar dan bersaing di kelas.

Berdasarkan simpulan hasil penelitian seperti tersebut di atas, bahwa TGT dapat meningkatkan hasil belajar peserta didik, maka disarankan hal-hal sebagai berikut: (1) Pada tahap perencanaan dapat dilaksanakan diskusi pembahasan permasalahan berupa latihan soal yang dianggap sulit oleh anggota tim maupun peserta didik, (2) TGT dapat dijadikan sarana peningkatan hasil belajar peserta didik pada mata pelajaran yang berbeda dimana peserta didik mengalami kesulitan dalam belajar teori dibandingkan dengan praktek, (3) Dalam pembelajaran, guru seharusnya selalu kreatif dalam 
proses kegiatan belajar mengajar sehingga dapat memotivasi peserta didik untuk lebih semangat dalam mengikuti pembelajaran.

\section{REFERENSI}

Fahruddin, F., Jufri, A. W., \& Jamaluddin, J. (2017). Pengaruh model pembelajaran kooperatif terhadap hasil belajar kognitif ditinjau dari kemampuan akademik mahasiswa. Jurnal Penelitian Pendidikan IPA, 2(1). https://doi.org/10.29303/jppipa.v2i1.27

Lastariwati, B. (2012). Pentingnya kelas kewirausahaan pada SMK pariwisata. Jurnal Pendidikan Vokasi, 2(1). https://doi.org/10.21831/jpv.v2i1.1018

Lie, A. (2008). Cooperative learning. Gramedia Widiasarana Indonesia.

Nurwidia, A., Haryanto, S., \& Mulyoto, M. (2019). Keefektifan teams games tournament dan make a macth dalam meningkatkan hasil belajar matematika. Annals of Mathematical Modeling, 1(1), 8-15. https://doi.org/10.33292/amm.v1i1.29

Undang-Undang Republik Indonesia nomor 20 tahun 2003 tentang sistem pendidikan nasional, Pub. L. No. 20, Undang-Undang Republik Indonesia 26 (2003).

van Wyk, M. M. (2011). The effects of teams-games-tournaments on achievement, retention, and attitudes of economics education students. Journal of Social Science, 26(3), 183-193. http://www.krepublishers.com/02-Journals/JSS/JSS-26-0-000-11-Web/JSS-26-3-000-11Abst-PDF/JSS-26-3-183-11-1132-Van-Wyk-M-M/JSS-26-3-183-11-1132-Van-Wyk -M-MTt.pdf 